\title{
SLC28 and SLC29 families of nucleoside transporters in GtoPdb v.2021.3
}

\author{
James R. Hammond ${ }^{1}$
}

1. University of Alberta, Canada

\begin{abstract}
Nucleoside transporters are divided into two families, the sodium-dependent, concentrative solute carrier family 28 (SLC28) and the equilibrative, solute carrier family 29 (SLC29). The endogenous substrates are typically nucleosides, although some family members can also transport nucleobases and organic cations [1].
\end{abstract}

\section{Contents}

This is a citation summary for SLC28 and SLC29 families of nucleoside transporters in the Guide to Pharmacology database (GtoPdb). It exists purely as an adjunct to the database to facilitate the recognition of citations to and from the database by citation analyzers. Readers will almost certainly want to visit the relevant sections of the database which are given here under database links.

GtoPdb is an expert-driven guide to pharmacological targets and the substances that act on them. GtoPdb is a reference work which is most usefully represented as an on-line database. As in any publication this work should be appropriately cited, and the papers it cites should also be recognized. This document provides a citation for the relevant parts of the database, and also provides a reference list for the research cited by those parts. For further details see [5].

Please note that the database version for the citations given in GtoPdb are to the most recent preceding version in which the family or its subfamilies and targets were substantially changed. The links below are to the current version. If you need to consult the cited version, rather than the most recent version, please contact the GtoPdb curators.

\section{Database links}

SLC28 and SLC29 families of nucleoside transporters

https://www.guidetopharmacology.org/GRAC/FamilyDisplayForward?familyId=149

SLC28 family

https://www.guidetopharmacology.org/GRAC/FamilyDisplayForward?familyId=215

Transporters

CNT1(Sodium/nucleoside cotransporter 1)

https://www.guidetopharmacology.org/GRAC/ObjectDisplayForward?objectId=1114

CNT2(Sodium/nucleoside cotransporter 2)

https://www.guidetopharmacology.org/GRAC/ObjectDisplayForward?objectId=1115

CNT3(Solute carrier family 28 member 3)

https://www.guidetopharmacology.org/GRAC/ObjectDisplayForward?objectId=1116

SLC29 family

https://www.guidetopharmacology.org/GRAC/FamilyDisplayForward?familyId=216

Transporters

ENT1(Equilibrative nucleoside transporter 1)

https://www.guidetopharmacology.org/GRAC/ObjectDisplayForward?objectId=1117

ENT2(Equilibrative nucleoside transporter 2)

https://www.guidetopharmacology.org/GRAC/ObjectDisplayForward?objectId=1118

ENT3(Equilibrative nucleoside transporter 3)

https://www.guidetopharmacology.org/GRAC/ObjectDisplayForward?objectId=1119

PMAT(Plasma membrane monoamine transporter)

https://www.guidetopharmacology.org/GRAC/ObjectDisplayForward?objectId $=1120$ 


\section{References}

1. Alexander SPH, Kelly E, Mathie A, Peters JA, Veale EL, Armstrong JF, Faccenda E, Harding SD, Pawson AJ and Sharman JL et al.. (2019) THE CONCISE GUIDE TO PHARMACOLOGY 2019/20: Transporters. Br J Pharmacol 176 Suppl 1: S397-S493 [PMID:31710713]

2. Armstrong D, Summers C, Ewart L, Nylander S, Sidaway JE and van Giezen JJ. (2014) Characterization of the adenosine pharmacology of ticagrelor reveals therapeutically relevant inhibition of equilibrative nucleoside transporter 1. J Cardiovasc Pharmacol Ther 19: 209-19 [PMID:24414167]

3. Baldwin SA, Yao SY, Hyde RJ, Ng AM, Foppolo S, Barnes K, Ritzel MW, Cass CE and Young JD. (2005) Functional characterization of novel human and mouse equilibrative nucleoside transporters (hENT3 and mENT3) located in intracellular membranes. J Biol Chem 280: 15880-7 [PMID:15701636]

4. Barnes K, Dobrzynski H, Foppolo S, Beal PR, Ismat F, Scullion ER, Sun L, Tellez J, Ritzel MW and Claycomb WC et al.. (2006) Distribution and functional characterization of equilibrative nucleoside transporter-4, a novel cardiac adenosine transporter activated at acidic pH. Circ Res 99: 510-9 [PMID:16873718]

5. Buneman P, Christie G, Davies JA, Dimitrellou R, Harding SD, Pawson AJ, Sharman JL and Wu Y. (2020) Why data citation isn't working, and what to do about it Database 2020 [PMID:32367113]

6. Cerveny L, Ptackova Z, Ceckova M, Karahoda R, Karbanova S, Jiraskova L, Greenwood SL, Glazier JD and Staud F. (2018) Equilibrative Nucleoside Transporter 1 (ENT1, SLC29A1) Facilitates Transfer of the Antiretroviral Drug Abacavir across the Placenta. Drug Metab Dispos 46: 1817-1826 [PMID:30097436]

7. Choi MK. (2012) Variability of gemcitabine accumulation and its relationship to expression of nucleoside transporters in peripheral blood mononuclear cells. Arch Pharm Res 35: 921-7 [PMID:22644860]

8. Choi MK, Kim MH, Maeng HJ and Song IS. (2015) Contribution of CNT1 and ENT1 to ribavirin uptake in human hepatocytes. Arch Pharm Res 38: 904-13 [PMID:25011570]

9. Daniels G, Ballif BA, Helias V, Saison C, Grimsley S, Mannessier L, Hustinx H, Lee E, Cartron JP and Peyrard T et al.. (2015) Lack of the nucleoside transporter ENT1 results in the Augustinenull blood type and ectopic mineralization. Blood 125: 3651-4 [PMID:25896650]

10. Engel K and Wang J. (2005) Interaction of organic cations with a newly identified plasma membrane monoamine transporter. Mol Pharmacol 68: 1397-407 [PMID:16099839]

11. Grañe-Boladeras N, Williams D, Tarmakova Z, Stevanovic K, Villani LA, Mehrabi P, Siu KWM, Pastor-Anglada M and Coe IR. (2019) Oligomerization of equilibrative nucleoside transporters: a novel regulatory and functional mechanism involving PKC and PP1. FASEB J 33: 3841-3850 [PMID:30521377]

12. Grañé-Boladeras N, Spring CM, Hanna WJ, Pastor-Anglada M and Coe IR. (2016) Novel nuclear hENT2 isoforms regulate cell cycle progression via controlling nucleoside transport and nuclear reservoir. Cell Mol Life Sci 73: 4559-4575 [PMID:27271752]

13. Gupte A and Buolamwini JK. (2009) Synthesis and biological evaluation of phloridzin analogs as human concentrative nucleoside transporter 3 (hCNT3) inhibitors. Bioorg Med Chem Lett 19: 917-21 [PMID:19097778]

14. Hammond JR. (2000) Interaction of a series of draflazine analogues with equilibrative nucleoside transporters: species differences and transporter subtype selectivity. Naunyn Schmiedebergs Arch Pharmacol 361: 373-82 [PMID:10763851]

15. Hammond JR and Archer RG. (2004) Interaction of the novel adenosine uptake inhibitor 3-[1(6,7-diethoxy-2-morpholinoquinazolin-4-yl)piperidin-4-yl]-1,6-dimethyl-2,4(1H,3H)quinazolinedione hydrochloride (KF24345) with the es and ei subtypes of equilibrative nucleoside transporters. J Pharmacol Exp Ther 308: 1083-93 [PMID:14634039]

16. Ho HT, Pan Y, Cui Z, Duan H, Swaan PW and Wang J. (2011) Molecular analysis and structureactivity relationship modeling of the substrate/inhibitor interaction site of plasma membrane monoamine transporter. J Pharmacol Exp Ther 339: 376-85 [PMID:21816955]

17. Hsu CL, Lin W, Seshasayee D, Chen YH, Ding X, Lin Z, Suto E, Huang Z, Lee WP and Park H et al.. (2012) Equilibrative nucleoside transporter 3 deficiency perturbs lysosome function and macrophage homeostasis. Science 335: 89-92 [PMID:22174130]

18. Kang N, Jun AH, Bhutia YD, Kannan N, Unadkat JD and Govindarajan R. (2010) Human equilibrative nucleoside transporter-3 (hENT3) spectrum disorder mutations impair nucleoside transport, protein localization, and stability. J Biol Chem 285: 28343-52 [PMID:20595384]

19. Larráyoz IM, Fernández-Nistal A, Garcés A, Gorraitz E and Lostao MP. (2006) Characterization of the rat $\mathrm{Na}+$ /nucleoside cotransporter 2 and transport of nucleoside-derived drugs using electrophysiological methods. Am J Physiol, Cell Physiol 291: C1395-404 [PMID:16837649]

20. Mimura Y, Yasujima T, Ohta K, Inoue K and Yuasa H. (2017) Functional Identification of Plasma Membrane Monoamine Transporter (PMAT/SLC29A4) as an Atenolol Transporter Sensitive to 
Flavonoids Contained in Apple Juice. J Pharm Sci 106: 2592-2598 [PMID:28089688]

21. Owen RP, Badagnani I and Giacomini KM. (2006) Molecular determinants of specificity for synthetic nucleoside analogs in the concentrative nucleoside transporter, CNT2.J Biol Chem 281: 26675-82 [PMID:16840788]

22. Stansberry WM, Swart M, Medeiros EB, Skaar TC and Pratt VM. (2018) Report of Confirmation of the rs7853758 and rs885004 Haplotype in SLC28A3. Genet Test Mol Biomarkers 22: 652-655 [PMID:30351207]

23. Stecula A, Schlessinger A, Giacomini KM and Sali A. (2017) Human Concentrative Nucleoside Transporter 3 (hCNT3, SLC28A3) Forms a Cyclic Homotrimer. Biochemistry 56: 3475-3483 [PMID:28661652]

24. Sundaram M, Yao SY, Ng AM, Griffiths M, Cass CE, Baldwin SA and Young JD. (1998) Chimeric constructs between human and rat equilibrative nucleoside transporters (hENT1 and rENT1) reveal hENT1 structural domains interacting with coronary vasoactive drugs. J Biol Chem 273: 21519-25 [PMID:9705281]

25. Tandio D, Vilas G and Hammond JR. (2019) Bidirectional transport of 2-chloroadenosine by equilibrative nucleoside transporter 4 (hENT4): Evidence for allosteric kinetics at acidic pH. Sci Rep 9: 13555 [PMID:31537831]

26. Tatani K, Hiratochi M, Nonaka Y, Isaji M and Shuto S. (2015) Identification of 8-aminoadenosine derivatives as a new class of human concentrative nucleoside transporter 2 inhibitors. ACS Med Chem Lett 6: 244-8 [PMID:25815140]

27. Wang C, Lin W, Playa H, Sun S, Cameron K and Buolamwini JK. (2013) Dipyridamole analogs as pharmacological inhibitors of equilibrative nucleoside transporters. Identification of novel potent and selective inhibitors of the adenosine transporter function of human equilibrative nucleoside transporter 4 (hENT4). Biochem Pharmacol 86: 1531-40 [PMID:24021350]

28. Wang J. (2016) The plasma membrane monoamine transporter (PMAT): Structure, function, and role in organic cation disposition. Clin Pharmacol Ther 100: 489-499 [PMID:27506881]

29. Warraich S, Bone DB, Quinonez D, Ii H, Choi DS, Holdsworth DW, Drangova M, Dixon SJ, Séguin CA and Hammond JR. (2013) Loss of equilibrative nucleoside transporter 1 in mice leads to progressive ectopic mineralization of spinal tissues resembling diffuse idiopathic skeletal hyperostosis in humans. J Bone Miner Res 28: 1135-49 [PMID:23184610]

30. Wright NJ and Lee SY. (2019) Structures of human ENT1 in complex with adenosine reuptake inhibitors. Nat Struct Mol Biol 26: 599-606 [PMID:31235912]

31. Yao SY, Ng AM, Cass CE, Baldwin SA and Young JD. (2011) Nucleobase transport by human equilibrative nucleoside transporter 1 (hENT1). J Biol Chem 286: 32552-62 [PMID:21795683]

32. Zhou M, Duan H, Engel K, Xia L and Wang J. (2010) Adenosine transport by plasma membrane monoamine transporter: reinvestigation and comparison with organic cations. Drug Metab Dispos 38: 1798-805 [PMID:20592246]

33. Zhou M, Xia L and Wang J. (2007) Metformin transport by a newly cloned proton-stimulated organic cation transporter (plasma membrane monoamine transporter) expressed in human intestine. Drug Metab Dispos 35: 1956-62 [PMID:17600084] 